УДК 81

ББК 80/84

DOI: https://doi.org/10.17308/lic.2021.2/3412

\title{
ИМПЛИЦИТНОСТЬ ПРОФЕССИОНАЛЬНОГО ЯЗЫКА ВОЕННОСЛУЖАЩИХ: СЕМАНТИКО-СТИЛИСТИЧЕСКИЕ НЮАНСЫ УСПЕШНОГО КОММУНИЦИРОВАНИЯ
}

\author{
Л. В. Молчанова, Л. Ю. Зубова \\ Военный учебно-научный центр Военно-воздушных сил «Военно-воздушная академия \\ имени профессора Н. Е. Жуковского и Ю. А. Гагарина»
}

\section{IMPLICITNESS OF THE MILITARY PROFESSIONAL LANGUAGE: SEMANTIC AND STYLISTIC NUANCES OF SUCCESSFUL COMMUNICATION}

\author{
L. V. Molchanova, L. Yu. Zubova \\ Military Educational and Scientific Center of the Air Force \\ "N. E. Zhukovsky and Yu. A. Gagarin Air Force Academy»
}

\begin{abstract}
Аннотация: в статье проводится анализ способов реализации категории имплицитности в военном профессиональном дискурсе. Рассматривается, каким образом степень имплицитности влияет на успешный обмен секретными данными среди профессионалов, на предотвращение утечек информации, соблюдение принцииа конфиденциильности. Реализация имплицитности анализируется в ракурсе сопоставления английского и немеикого военных дискурсов. Актуальность исследования обусловлена тем, что напряженная обстановка в мире, касающаяся обеспечения экологии киберпространства на самом высоком уровне государственности, предполагает искусство сохранять неуязвимость своих критических данных даже при самом неблагоприятном развитии событий. Умение учитывать и применять имплицитность при создании и оперировании терминами в ходе осуществления профессиональной коммуникации является одним из главенствующих факторов получения превосходства над противником, ограничения доступа $\kappa$ специальной информаџии для непосвященных и оптимизации общения между специалистами военной отрасли. Наше исследование посвящено изучению профессионализмов, которые характеризуются высокой степенью имплицитности (аббревиатуры, кодовые обозначения и эвфемизмы). Нами проведен структурно-семантический анализ имплицитных ЛЕ в родственных языках (английском и немецком). Сделанные нами выводы позволяют оценить актуальность, динамичность и масштаб влияния имплицитности на процесс терминологического моделирования в современных профессиональных языках. Нами задается перспектива дальнейших исследований в отношении значимости имплицитных терминов для успешного терминотворчества. Практическую значимость составляет возможность использования материалов исследования в курсе лексикологии, а также для обучения военных переводчиков (189 слов).

Ключевые слова: имплицитность, аббревиатура, эвфемизм, метафора, кодовое обозначение, военный дискурс.
\end{abstract}

\begin{abstract}
: the article analyzes the ways of implementing the category of implicitness in the military professional discourse. The article examines how the degree of implicitness affects the successful exchange of secret data among professionals, the prevention of information leaks, and the observance of the principle of confidentiality. The relevance of the study is due to the fact that the tense situation in the world, concerning the ecology of cyberspace at the highest level of statehood, involves the art of preserving the invulnerability of their critical data, even in the most unfavorable development of events. Taking implicitness into account when creating and operating
\end{abstract}

( С Молчанова Л. В., Зубова Л. Ю., 2021

Контент доступен под лицензией Creative Commons Attribution 4.0 License.

The content is available under Creative Commons Attribution 4.0 License. 
terms in the course of professional communication enables gaining superiority over the enemy, restricting access to special information for the unwanted. Our research is devoted to abbreviations, code designations, and euphemisms that are characterized by a high degree of implicitness. We conducted structural and semantic analysis of implicit terms in related languages (English and German). Our conclusions allow us to assess the relevance, dynamism and influence of implicitness in modelling terms in modern professional languages. The practical significance is the possibility of using the research materials in the course of lexicology, as well as for training military translators (200 words).

Key words: implicitness, abbreviation, euphemism, metaphor, code designation, military discourse.

\section{Введение}

Профессиональная военная сфера является благодатной почвой для изучения, так как обладает структурно-семантическим многообразием и богатой контекстуальной базой. Все новые и новые достижения и разработки стимулируют появление новых терминов. В свою очередь, называя феномен или устройство, терминологические единицы должны обладать «выборочной доступностью», т. е. не привлекать внимания тех, для кого они не предназначены, и в то же время максимально полно характеризовать объект, облегчая работу специалистам. Терминологические классы, анализируемые нами в данной работе, в полной мере соответствуют названным критериям. Это аббревиатуры (в том числе омоакронимы), кодовые обозначения и эвфемизмы.

Основанием, благодаря которому мы считаем целесообразным отнести перечисленные лексические единицы именно к терминам, нам представляется классификация военной лексики, предложенная Г. А. Судзиловским [1, с. 3], однако не все так однозначно. На первый взгляд, аббревиатуры относятся сугубо к официальной терминологии (LSP - Language for Special Purposes), однако если рассмотреть корреляты омоакронимов, то многие из них эмоционально окрашены. Например, омоакроним HARM (High Velocity Anti-Radiation Missile - высокоскоростная противорадиолокационная ракета «Харм») метафорически соотносится с коррелятом harm (вред, ущерб), обладающим однозначно отрицательной коннотацией; омоакроним НАWK (Homing-All-theWay-Killer - зенитно-ракетный комплекс самонаводящихся ракет «хок») имеет коррелят hawk (ястреб, амер. сленг - сторонник решения спорных вопросов военным путем) - негативно-оценочный компонент значения используется для передачи ироничного отношения к применяющим данный тип оружия.

То же относится к кодовым обозначениям, сигнификат которых гораздо масштабнее и богаче, чем референция простого, эксплицитного термина, так как первый включает фоновую историко-культурную информацию с вкраплениями оценочного компонента и не случайно получил название концептуальной метафоры, о чем речь пойдет далее. Например, кодовому обозначению SOCRATES (Special Operations
Intelligence Vehicle-Man Transportable Station - Возимая и переносная система связи и разведки для сил специальных операций «Сократ») присуща сугубо положительная коннотация.

В самом явлении эвфемизации изначально заложена положительная коннотация, что, согласно классификации Г. А. Судзиловского, относит эвфемизмы к неуставной терминологии (LGP - Language for General Purposes), употребляемой в устной речи военнослужащих и в некоторых видах военной литературы, но не являющейся официально принятой [1, с. 4]. Мы считаем целесообразным отнести эвфемизмы к профессиональным жаргонизмам, так как вслед за И. Р. Гальпериным определяем жаргон как группу слов, целью которых является сохранение секретности той или иной социальной группы [2, с. 110] или группы лиц, объединенных каким-либо родом деятельности. Такого рода лексика является непонятной для лиц, не входящих в эти группы. Например, adventure means a war (приключение означает война); catch a packet means to be killed or severely wounded (поймать пакет означает быть убитым или тяжелораненым).

В разной степени перечисленным единицам присуща имплицитность - характеристика, которая их объединяет и ставит на высокий уровень значимости в военном профессиональном дискурсе. Напомним, что термин имплицитныьй (скрытый) происходит от английского implicit - подразумеваемый, невыраженный [3, с. 174]. Ряд лингвистов (Л. В. Лисоченко, Ю. М. Скребнев, А. О. Бегинина, Л. К. Байрамова, П. А. Вяземский, Т. С. Оганезова, С. К. Фоломкина, Н. Д. Арутюнова) связывают термин имплицитность с пониманием выражения опосредованно, как выражения со скрытым смыслом. В тексте имплицитность проявляет себя как подтекст, выражающий авторскую идею, концепцию, которая задает смысл текста. Однако А. В. Бондарко относит имплицитность к аспектам категоризации и семантики, наряду с инвариантностью/вариативностью элементов семантического содержания, что вполне оправданно [4]. Наиболее общее определение понятия дает Н. Д. Арутюнова. Она считает имплицитность следствием фундаментального свойства языка, где план содержания гораздо шире и объемнее, чем план выражения. Как пишет 
Н. Д. Арутюнова, «человек воспринимает больше, чем может выразить язык. За его пределами остается несказанное, невыразимое, ненареченное, неизреченное» [5].

Традиционно выделяют три формы имплицитности, акцентируя внимание на структуре, функции и смысле понятия [6]. Нас будут интересовать две первые формы имплицитности: та семантика, которая остается за скобками структуры, и функция термина, которая зависит не от структуры, а от экстралингвистических факторов.

Изменившаяся за последние десятилетия картина профессиональной сферы показывает, насколько подробным стал терминологический корпус, насколько усложнился структурно-семантический уровень терминов, насколько поменялось количественное соотношение формы и содержания терминологического единства. Мы можем сделать вывод также об изменении уровня научного мышления, которое привычно оперирует сложными терминами. В связи с этим некоторые ученые приводят термин «аббревиатурное мышление».

Однако мы уже говорили о том, что при работе с критической, секретной информацией на первое место выходит критерий «закрытости» номинируемой информации, ее доступности исключительно для избранных [7]. Таким образом, степень имплицитности термина становится критической характеристикой для военной сферы, где должна соблюдаться строгая конфиденциальность на любом этапе работы со специальной информацией для предотвращения утечки данных. Так, можно утверждать, что все термины и профессиональные жаргонизмы в той или иной степени являются кодировкой специальной информации.

\section{Материалы и методы}

Методологической базой исследования послужили идеи и концепции, представленные в трудах отечественных и зарубежных лингвистов по имплицитности (Н. Д. Арутюнова, А. В. Бондарко, В. D. Homer, J. T. Ramsay и др.), кодовым обозначениям (Л. В. Порохницкая, Ю. А. Соловьева, G. Sieminsky и др.), аббревиации (И. В. Арнольд, М. А. Ярмашевич и др.) и эвфемии (Ю. Н. Караулов, С. А. Киселева, Л. П. Крысин, Л. Н. Шапина, Н. Rawson, R. W. Holder и др.).

Научная новизна исследования мотивируется тем, что в нем впервые проанализированы термины военной сферы с высоким уровнем имплицитности в ракурсе эффективности осуществления профессионального дискурса. Произведен сопоставительный анализ соответствующих единиц в английском и немецком языках на материале современных СМИ, а также словарей аббревиатур и эвфемизмов.
Теоретическая значимость исследования заключается в уточнении статуса анализируемых имплицитных единиц, их соотношения в военном дискурсе.

Практическая значимость исследования заключается в возможности использовать представленные материалы и выводы в практике вузовского преподавания иностранного языка и терминоведения курсантам и слушателям, в частности, при чтении курсов и спецкурсов для военных переводчиков. Кроме того, знание методов и приемов работы с имплицитными терминами позволяет оптимизировать профессиональную коммуникацию и предотвратить манипуляции противника, способные нанести ущерб военной и государственной безопасности нашей страны.

Лексика, используемая в профессиональной коммуникации, достаточно многообразна. Однако именно аббревиатуры, кодовые названия, шифры и эвфемизмы наглядно демонстрируют использование законов семиотики для оптимизации военного дискурса.

Итак, применительно к терминам мы рассматриваем имплицитность как свойство вмещать скрытый смысл, который выражен не только и не столько формой термина, сколько задается экстралингвистической ситуацией или контекстным окружением. Интересно, что данная трактовка ставит под сомнение некогда устойчивый стереотип, что термин должен быть однозначным, предельно ясным (explicit), чуждым полисемии и, тем более, омонимии. Иными словами, считалось, что знак-термин инвариантен в смысловом отношении и передает однозначную информацию [8, с. 129]. Однако языку присуще явление полисемии: разные значения одного языкового знака актуализируются в определенном речевом контексте. Следовательно, непонимание контекста может привести к неверной интерпретации знака, к дезинформированности о факте действительности. Имплицитные термины не являются исключением из этого правила.

Рассмотрим на примерах, как в военной терминологии реализуются полисемия, омонимия, синонимия и эвфемия - все то, что традиционно не должно присутствовать в профессиональной коммуникации, дабы не вносить в нее двусмысленность, субъективность и неопределенность (таблица).

Что касается явления абсолютной синонимии, то она может приводить к неоправданному увеличению количества терминологических единиц, что затрудняет работу с ними.

Сравним: (англ.) Electronic countermeasures = Electronic attack (радиоэлектронное подавление); altitude = height (вblcoma); velocity = speed (cкорость).

Сравним: (нем.) Motor $=$ Triebwerk $=$ Antrieb (двигатель); Einsatzfahrzeug = Gefechtsfahrzeug (боевая машина). 
Примеры реализации языковых явлений в военной терминологи

\begin{tabular}{|c|c|c|}
\hline Языковое явление & Английский язык & Немецкий язык \\
\hline Полисемия & $\begin{array}{l}\text { intelligence: } \\
\text { 1) разведданные; } \\
\text { 2) разведка. } \\
\text { weapon: } \\
\text { 1) оружие; } \\
\text { 2) орудие } \\
\end{array}$ & $\begin{array}{l}\text { Abschubtransport: } \\
\text { 1) эвакуационный транспорт; } \\
\text { 2) эвакуационные воинские перевозки. } \\
\text { Abteilung: } \\
\text { 1) отдел (штаба); } \\
\text { 2) отделение (взвода) } \\
\end{array}$ \\
\hline Омонимия & $\begin{array}{l}\text { train: } \\
\text { 1) автоколонна; } \\
\text { 2) тренировать; } \\
\text { 3) направить орудие }\end{array}$ & $\begin{array}{l}\text { Verzögerung: } \\
\text { 1) промедление, замедление; } \\
\text { 2) сдерживающие воинские действия. } \\
\text { Aufklärung: } \\
\text { 1) разведка; } \\
\text { 2) эпоха просвещения } \\
\end{array}$ \\
\hline Синонимия частичная & $\begin{array}{l}\text { reconnaissance: } \\
\text { разведка (an examination or survey of } \\
\text { ground or a specific location, in order to } \\
\text { plan an operation). } \\
\text { intelligence: } \\
\text { разведка (people and equipment involved } \\
\text { in the gathering, analysis and dissemination } \\
\text { of information about the enemy) }\end{array}$ & $\begin{array}{l}\text { Gerät: } \\
\text { прибор (Werkzeug, Instrument). } \\
\text { Anlage, Einrichtung: } \\
\text { прибор, установка, оборудование (Gesamt der } \\
\text { Gegenstände, mit denen etwas eingerichtet ist) }\end{array}$ \\
\hline Эвфемия & $\begin{array}{l}\text { collaborator: } \\
\text { copaтник, сотрудник (означает предатель). } \\
\text { freedom fighters: } \\
\text { борцы за свободу (означает террористы) }\end{array}$ & $\begin{array}{l}\text { Wühlschwein: } \\
\text { землеройка (означает танк-тральщъик). } \\
\text { tilgen: } \\
\text { гасить, стирать, погашать (означает уничтожать) }\end{array}$ \\
\hline
\end{tabular}

Почему возникает такой парадокс? Что мешает единообразию терминологии? На первый взгляд, вышеперечисленные явления кажутся недостатками. На самом деле они обеспечивают имплицитность профессионального дискурса, так необходимую для сохранения конфиденциальности. Ведь именно неопределенность вводит в заблуждение дилетанта, который, в отличие от профессионала, не знает, за какое из нескольких значений «ухватиться».

Рассмотрим каждый из перечисленных классов более детально, чтобы выявить степень проявления имплицитности в каждом из них и оценить значимость каждого класса для образования и функционирования специальных военных терминов.

Аббревиатуры, или сокращения, зачастую функционируют в профессиональном языке наряду с развернутыми терминами - их прототипами. Однако у сокращенных единиц есть преимущество. Е. С. Кубрякова отмечает, что прототип и аббревиатура имеют разные способы представления содержания. Они отличаются не столько извлекаемой из них информацией, сколько мерой ее эксплицитности [9, с. 24]. Иными словами, эксплицитная модель (прототипа) заменяется имплицитной (аббревиатуры) [10, с. 27], что приобретает особую ценность в профессиональном подъязыке военнослужащих.

Аббревиатуры разнообразны по структуре. Сoгласно предложенной нами структурной классифи- кации аббревиатуры делятся на инициальные, усечения, частично и сложносокращенные слова, слова-слитки, стяжения и рамочные [11]. Каждый класс отличается большей или меньшей степенью имплицитности. Наблюдается следующая четкая закономерность. Чем более «свернута» графическая форма, тем больше потенциальная валентность аббревиатуры. Одиночная аббревиатура часто реализует свою многовалентность, становясь основой терминологического сочетания, выраженного также в аббревиатурной форме. Так возникают аббревиатурные комплексы. К примеру, в английском языке аббревиатурный комплекс NACOSA состоит из аббревиатур NATO, CIS и словосочетания Operating and Support Agency (Управление по эксплуатации и обслуживанию систем связи и информации НАТО), а в немецком языке EloKa - это Elektronischer Kampf (борьба с радиоэлектронными средствами противника). Информативная емкость подобных комплексов крайне высока, что составляет контраст с компактной графической реализацией. Так, инициальные аббревиатуры и аббревиатурные комплексы (в том числе омоакроHuмbl) обладают самой высокой степенью имплицитности, так как сжатая до инициалов форма является лишь намеком, указателем на сложное, объемное понятие или даже директиву. Например, омоакроним SURVIVAL вмещает в себя принципы поведения военнослужащего при внештатной ситуации [7]: 
$\mathrm{S}$ - Size up your situation, time and surroundings, your physical condition and your equipment. (Оцени свои ситуацию, время и окружение, а также физическое состояние и экипировку.)

$\mathrm{U}$ - Undue haste makes waste; don't be too eager to move. (Ненужная спешка приводит к потерям. Не суетись.)

$\mathrm{R}$ - Remember where you are in relation to important friendly and critical resources. (Всегда помни расположение союзников, союзных позиций и экстренных служб.)

$\mathrm{V}$ - Vanquish fear and panic. (Отбрось страх и панику.)

I - Improvise. Use your imagination to improve the situation. (Импровизируй. Подключай воображение и не сдавайся. Ты всегда можешь улучшить ситуацию.)

V - Value your life. Remember your goal: to get out alive. Remain stubborn. Refuse to give in to problems and obstacles that face you. This will give you the mental and physical strengths to endure. (Знай цену своей жизни. Не забывай о главном: ты должен остаться в живых. Сопротивляйся. Не отступай перед трудностями. Это поможет тебе выстоять.)

A-Act like the natives do. (Веди себя как местные жители; наблюдай за их повседневной деятельностью.)

L - Live by your wits. Learn basic skills. (Живи своим умом. Приобретай базовые навыки выживания.)

Так, на поверхности находится мизерная часть (SURVIVAL), в которой лишь специалисты опытным взглядом могут распознать верхушку айсберга - гигантского терминологического конгломерата.

Соответственно, усечения наименее имплицитны, так как их прототипами являются единичные термины, а не терминологические комплексы. Следовательно, графическая внешняя оболочка довольно полно передает название развернутого термина-прототипа. Если использование в военном дискурсе инициальных аббревиатур вуалирует данные определенного рода, пресекая их нежелательное распространение, то роль усечений сводится к сугубо языковой экономии, когда усекаются те части слова, которые не несут смысловой нагрузки и чье отсутствие не мешает пониманию ЛЕ. Например, (англ.) intel - intelligence (разведка).

Итак, можно условно расположить инициальные аббревиатуры и усечения на противоположных полюсах, характеризующих крайнюю степень имплицитности и ее отсутствие. Между ними примерно на одном уровне будут находиться частично и сложносокращенные слова и слова-слитки, так как развернутые прототипы всех трех классов можно достаточно легко восстановить, владея понятийно-терминологическим аппаратом военной специальности.
Стяжения приближаются по уровню имплицитности к инициализмам, в силу того что в одну аббревиатуру соединяются произвольно выбранные элементы термина-прототипа. Например, INTACS (Integrated Tactical Communications System - Объединенная войсковая система связи). Здесь мы можем наблюдать пример терминологического моделирования, когда образ нового терминологического комплекса-аббревиатуры не складывается постепенно в процессе ее ассимиляции в языке, а сознательно создается человеком для успешного функционирования термина в языке с учетом таких факторов, как благозвучность, связь с прототипом, краткость, запоминаемость и т. д. Другим примером является AWACS (Airborne Early Warning and Control System - Авиационная система дальнего радиолокационного обнаружения и управления «Авакс»).

Рамочные аббревиатуры, на первый взгляд, представляются родственными инициализмами, однако при более глубоком анализе выявляется существенное отличие. Любая рамочная аббревиатура представляет не словосочетание, не комплекс, а моновербныцй терминологический прототип. «Вычислить» его поэтому довольно легко: (англ.) acft - aircraft (летательный аппарат), cmdr - commander (командир, командующий); (нем.) PiKp - Pionierkompanie (саперная рота), Kdr - Kommandeur (командир). Однако бывают и исключения, когда в аббревиатуру входят не все «выстраивающие рамку» элементы, например, соу - company (рота) в английском языке и Fla - Flugabwehr (ПВО) в немецком языке. В этом случае восстановить прототип бывает не просто. Таким образом, за кажущейся имплицитностью кроется довольно-таки разборчивая структура: универб, намеченный отдельными графемами как пунктиром. Сравним: многочленная инициальная аббревиатура имеет в качестве прототипа (расшифровки) поливерб, состоящий из нескольких моновербных терминов. Так, инициализм можно разложить на элементы, т. е. за каждой графемой, за каждым символом будет стоять самостоятельный термин. В рамочной аббревиатуре, наоборот, несколько графем передают один моновербный прототип. Отдельная графема сама по себе не имеет смысла, за ней не стоит самостоятельный термин она функционирует только вместе с другими «пунктирными линиями», составляя с другими графемами общий рисунок не комплексного, поливербного, а простого, моновербного термина. Иными словами, «за скобками» не остается практически ничего, поэтому и уровень имплицитности рамочных аббревиатур низок.

Частным случаем инициальной аббревиации и еще одним ярким примером терминологического моделирования является омоакронимия - построение акронимов (вида инициальных аббревиатур, читаю- 
щихся как слово, а не по буквам, благодаря чередованию гласных и согласных) таким образом, чтобы они совпадали по форме с общеупотребительными словами. Разница заключается в инициальной графике и существовании развернутого прототипа для каждого инициального компонента аббревиатурного комплекса. Сравним: (англ.) омоакроним (в дальнейшем OA) AEGIS - его развернутый прототип Airborne Early Warning Ground Integration Segment (встроенная система предупреждения воздушной угрозы) \| его коррелят (обычное несокращенное слово) aegis (эгида); (нем.) FLUK - Flugkörper (летательный аппарат, ракета) || его коррелят die Fluke (хвостовой плавник у китов и морских коров).

Соответственно, моделирование ОА, т. е. намеренную «подгонку» аббревиатурного комплекса под общеупотребительное слово, мы считаем коррелятивной аббревиацией вслед за И. В. Арнольд и Е. Н. Ардаматской [12]. ОА демонстрирует, каким должен быть идеальный военный термин: с одной стороны, он краток по форме и объемен по содержанию, с другой стороны, он отлично запоминается, давая простор воображению и стимулируя ассоциации, связанные с личным опытом. Более того, он в высшей степени имплицитен, сохраняя специальную информацию для целевых участников дискурса. Напротив, для не-специалиста коррелят часто является отвлекающим фактором в понимании ОА и расшифровке его прототипа. Возможны несколько вариантов связи прототипа и коррелята. Бывает, что связь отсутствует, и это крайний предел имплицитности. Так происходит в ОА, где коррелятом является имя собственное, лексическое значение которого в речи не функционирует. Например, в английском языке ADAM - Area Denial Artillery Munition (Apтиллерийские боеприпасы для блокирования района), сравним коррелят Адам - мужское имя, хотя слово имеет свое значение - вылепленный из глины; в немецком языке LARS - Leichtes Artillerie-Raketenwerfersystem (110-мм 36-ствольная реактивная пусковая установка). Коррелятом этой аббревиатуры является тоже мужское имя Ларс; MOSEL - Modifziertes operationelles System (модифицированная операционная система), коррелят - die Mosel (река Мозель). Более благоприятный вариант для изучения и запоминания - это метафорическая связь между прототипом и коррелятом. Например, OA MARINE - Muscles Are Required, Intelligence Not Expectedкоррелят Морская пехота / Сила есть -ума не надо. Если в качестве коррелята выбирается стилистически нейтральное слово (как в приведенном примере), то форма созданного ОА не передает заключенного в нем оценочного компонента, тем более не очевиден ироничный подтекст. Строго говоря, ОА такого типа относятся не к терминам, а к профессиональным жаргонизмам. В данном примере четко прослеживается «подгонка» под коррелят.

Есть примеры, где ОА выполняют роль подсказки, можно сказать, плана, инструкции, руководства к действию. ОА такого рода мы назвали мнемограммы - т. е. правила, информация для запоминания. Например, существует мнемограмма SALUTE, которая подсказывает разведчику, какого рода информацию о противнике он должен запомнить:

$\mathrm{S}$ - Size (численность противника);

A - Activity (недавние действия противника);

L - Location (где располагается противник);

U - Unit (какое подразделение);

T - Time (когда противник был замечен);

E - Equipment (чем противник вооружен, оснащен).

Другой пример - мнемограмма SURVIVAL (см. выше), каждый инициальный компонент которой скрывает даже не слово, а целый абзац, мини-ситуацию.

Таким образом, хотя существует определенная метафорическая связь между прототипом и коррелятом ОА и хотя ОА отличает от общеупотребительного слова инициальная графика, далеко не очевидна трактовка каждого инициального компонента аббревиатуры, что ставит ОА в ранг лексики с высокой степенью имплицитности, как, впрочем, и остальные инициальные аббревиатуры. Вкратце, произвольно выбираемая для создания ОА форма коррелята, как правило, не отражает содержания стоящего за ней развернутого терминологического прототипа. Внутри каждого ОА как знака постоянно происходят семантические изменения в двух направлениях: между ОА и прототипом; между ОА и коррелятом. Причем прототип постепенно отходит на второй план, в то время как коррелят становится более значимым. ОА начинает ассоциироваться с коррелятом, который обогащается дополнительным значением - расшифровкой-прототипом. Грамотное оперирование омоакронимами экономит время на расшифровку омоакронима, перевод и толкование прототипа. Значение настолько плотно «прикипает» к корреляту, что ОА заслуженно приобретает статус почти кодового обозначения. Например, OA SNOWCAT - Support of Nuclear Operations with Conventional Air Tactics (Поддержка операций по нанесению ядерных ударов с использованием тактики действий обычных ВBC), коррелят snowcat - снегоход. Или в немецком языке: OA MOPS - maschinenorientiertes Programmiersystem (машинно-ориентированная система программирования), коррелят $\operatorname{der} M o p s$ - мопс, порода собак. Эта особенность позволяет нам отнести ОА к немотивированным лексическим единицам, что роднит их со следующим рассматриваемым нами классом профессионализмов - кодами и шифрами. 
И коды, и шифры относятся к немотивированным единицам, так как специалисты одной области договариваются о присвоении тому или иному графическому символу (букве или цифре) или их комбинации (в том числе лексической единице) определенного значения. Сверимся с определением, данным в словаре: код - система условных знаков (символов) для обработки, передачи и хранения информации [13, c. 500].

Можно дополнить, что код - это некая ограниченная упорядоченная комбинация символов (например, омоакроним), получившаяся в результате проекции множества символов (например, развернутого прототипа) на плоскость имплицитности и языковой экономии.

Шифр ( $p p$. chiffre, буквально - цифра, от араб. صفُر sifr «ноль») - совокупность условных знаков (условная азбука из цифр или букв) для секретной переписки дипломатических представителей со своими правительствами, а также в вооруженных силах для передачи текста секретных документов по техническим средствам связи [14].

В отличие от кодирования отдельных понятий шифры обычно более масштабны и используются для передачи большего объема информации (сообщений или целого текста). По причине того, что это слишком обширная тема, мы не имеем ни возможности, ни намерения детально проанализировать в данной статье создание и функционирование шифров.

Тем не менее мы рассмотрим феномен кода с точки зрения имплицитности: какую информацию скрывают коды и какие средства для этого используются.

Между кодовым обозначением и его означаемым условно устанавливается связь. Возникает знаковая ситуация с воспринимающим субъектом (специалистом), означаемым (мыслительным образом и обозначаемым объектом) и системой других подобных знаков, в которой означающее - определенный лексикализованный фрагмент действительности - занимает свое место.

Коды могут быть с использованием слов и без использования слов (комбинации чисел, букв и чисел, а также только букв, но это не аббревиатуры, потому что они не являются сокращенной версией развернутого прототипа). Нас, конечно же, будут интересовать коды с использованием слов, так как имплицитность кодов без использования слов очевидна.

Для примера возьмем коды моделей самолетов и видов оружия. Причем американская система кодов для самолетов и оружия отличается от отечественной. Например, российский стратегический бомбардировщик ТУ-160 получил кодовое название Белый лебедь (в российской классификации) и Blackjack (Черный валет) (в классификации НАТО); российский воен- но-транспортный самолет АН-124 получил кодовое название Руслан (в российской классификации) и Condor (в классификации НАТО), российский разведывательно-ударный вертолет КА-52 получил кодовое название Аллигатор (в российской классификации) и Hokum (обманщик) (в классификации НАТО).

Можно сказать, что и КА-52, и ТУ-160 получили свои российские названия благодаря метафорическому переносу (самолет похож на белого лебедя с распластанными крыльями, а вертолет - на длинного зеленого крокодила). Такой же перенос наблюдается с названиями Condor (мощная крупная птица), и Руслан (русский богатырь, большой и сильный). Метафорический перенос в названиях Hokum и Blackjack не так очевиден. Метафора скрыта и связана не с внешними признаками, а с техническими характеристиками (маневренный, умеющий застать врасплох, выигрышный вариант) объекта.

В ВВС Германии тоже есть исконные кодовые обозначения боевых самолетов и комплексов, но для тех моделей, которые производит Германия, напримep, Ozelot - самоходный зенитно-ракетный комплекс (хищное млекопитающее из семейства кошачьих); Mantis - зенитно-артиллерийский ракетный комплекс (богомол).

В своей работе, посвященной англоязычному военно-политическому дискурсу, Ю. А. Соловьева утверждает, что в основе номинации, связанной с кодовыми названиями, лежит такое явление, как «концептуальная метафора». При помощи концептуальной метафоры можно объяснить появление оценочных значений и коннотаций [15, с. 44].

Л. В. Порохницкая отмечает, что под данным термином «традиционно понимается представление одной области (области цели, target domain) в терминах другой области (области источника, source domain), причем концептуальная область-донор в большинстве случаев более конкретна и четче очерчена, чем область цели» [16, с. 105].

Помимо различных видов техники, благодатной почвой для кодирования являются боевые операции. Умение эффективно подбирать названия для военных операций является мощным средством победы в войне еще на этапе обдумывания. «Это первая выпущенная пуля и, вполне возможно, самая критическая. В случае правильного использования название может стать ключевым компонентом, приводящим к победе» [17].

Интересно, что практика присвоения кодовых названий военным операциям началась сравнительно недавно (меньше ста лет назад - во время Первой мировой войны). Предположительно, основоположником стал немецкий генеральный штаб (German General Staff), который использовал кодовые названия, прежде всего, чтобы сохранить меры обеспече- 
ния секретности операций. Немцы выбирали названия, которые были не только запоминающимися, максимально скрывающими суть проводимых военных действий, но и вдохновляющими военнослужащих [18, с. 105].

Согласно докладу Г. Симински, в 1918 г. наибольшее количество кодовых названий военных операций было заимствовано из религиозных, средневековых и мифологических источников, например, Archangel, St. George, Mars, Achilles, Valkyrie, St. Michael и т. д. $[17$, p. 3]. Рассмотрим некоторые из них.

Очевидно, что все вышеперечисленные названия имеют отношение к войне, однако не называют место и цель проводимой операции, что указывает на тщательность их отбора. Таким образом, Архангел-старший из ангелов, Святой Георгий - покровитель Англии, который, став солдатом, был убит в Палестине из-за своих христианских убеждений. Марс - бог войны в римской мифологии. Ахиллес-герой, величайший греческий воин. Валькирии - воинственные девы, забиравшие души самых храбрых воинов.

Выбор этих имен был, несомненно, дополнением к патриотической программе обучения Э. Людендорфа (немецкого генерал-полковника, автора «концепции войны», разработанной для того, чтобы расшевелить деморализованную и утомленную армию.

Годы спустя после окончания Второй мировой войны прием кодирования названий военных операций продолжает использоваться как эффективный способ сокрытия конфиденциальной информации: Eldorado Canyon - Каньон Эльдорадо (рейд в Ливию в 1986 г.), Praying Mantis - Богомол (воздушная атака в 1988 г. по военным кораблям и нефтяным платформам Ирана) и Golden Pheasant - Золотой фазан (демонстрация военной силы 1988 г. для предотвращения конфликта между Никарагуа и Гондурасом). Первая война в Персидском заливе получила название Desert Storm («Буря в пустыне»), которое опосредованно описывало эффект, ожидаемый от кампании.

Проанализировав многочисленные кодовые названия военных операций, можно сделать вывод о том, что при кодировании необходимо учитывать следующие факторы:

1) название должно быть запоминающимся, но стилистически и концептуально нейтральным (не содержащим оценочного компонента);

2) название должно максимально скрывать суть проводимых военных действий, т. е. оно не должно содержать ключевых слов и понятий, которые могут нарушить конфиденциальность операции - в этом принципе реализуется категория имплицитности;

3) название должно быть стимулирующим для военнослужащих, но не должно нести признаков самодовольства;
4) название не должно включать негативных оценок в адрес страны, где планируется проводить операцию.

Владение военными омоакронимами, специальными кодами и шифрами позволяет специалисту преодолеть рамки имплицитности и получить доступ к закрытой информации, оперирование которой дает преимущество профессионалам военной сферы перед случайными обывателями, является показателем грамотности и уровня квалификации специалиста.

Несмотря на различия в представлении информации, инициальные аббревиатуры (в том числе ОА), коды и шифры выполняют в профессиональном военном дискурсе схожую функцию - сокрытие данных от непосвященных, безопасное хранение, передача и оперирование ими, что является залогом превосходства на фоне менее искусного противника.

Однако все вышеизложенные преимущества имеют свою оборотную сторону - чрезмерная закрытость информации при отсутствии или недостаточных навыках работы с имплицитными терминами приводит к двусмысленности восприятия, неточности перевода, что в условиях военного дискурса критично.

Вследствие того, что основной задачей при номинации военных действий является полная конфиденциальность, а многие названия закамуфлированы, то можно предположить, что здесь также речь идет об эвфемии, которая не имеет задачи «разоблачать», а наоборот - «скрывать» и «ретушировать». Поэтому следующая заявленная нами категория имплицитных профессионализмов - эвфемизмы.

Напомним, что термин «эвфемизм» происходит от греч. euphemismos (еu - «хорошо», phemi - «говорю»; euphemeo - «говорю вежливо»; euphemia - «благоречие, хорошая речь; воздержание от неподобающих слов») [19, с. 636].

Эвфемизмы иногда метафорически называют «a whitewashing device»-букв. средство для побелки, т. е. прием для приукрашивания, сглаживания реальных фактов.

Большинство ученых, анализировавших эвфемизмы (Ш. Балли, Л. Блумфилд, И. Р. Гальперин, Ю. Н. Караулов, Л. П. Крысин, Е. И. Шейгал, Г. Г. Кужим, В. И. Заботкина, В. П. Москвин и др.), акцентируют внимание на их функции сглаживать неприятное в речи:

«Эвфемизмы - эмоционально нейтральные слова или выражения, употребляемые вместо синонимичных им слов и выражений, представляющихся говорящему неприличными, грубыми или нетактичными [20, с. 592].

Интересна мысль О. А. Михайловой о том, что чтобы стать эвфемизмом, прямое наименование должно создавать ассоциации в сознании говорящего и слушающего с предметом или явлением более по- 
зитивной оценки, чем денотат [21, с. 280]. Если рассматривать военный дискурс, то нейральной ассоциации достаточно, чтобы заместить негативную. Например, go over the hill (пойти за холм) вместо to escape or desert (дезертировать).

Н. Е. Кирсанова уточняет: «Эвфемизмы - это единицы вторичной номинации с относительно положительной коннотацией, которые используются для замены прямых наименований, употребление которых по социально или психологически предопределенным причинам считается нежелательным» [22, c. 170].

Интересна точка зрения Л. Н. Шапиной, которая рассматривает эвфемию как особую стратегию использования слов, соотносящуюся с более широкой коммуникативной стратегией неопределенности [23].

Из возможных целей эвфемизации, выделенных Л. П. Крысиным, в военном профессиональном дискурсе на первый план выходят следующие:

- стремление завуалировать истинную сущность явления;

- стремление сообщить нечто адресату таким образом, чтобы это было понятно только ему [24].

Иногда главной становится цель под номером два - завуалировать истинную сущность явления (например, для смягчения жестоких явлений или событий во избежание негативного психологического воздействия на реципиента, как это делается в СМИ для поддержания положительного образа воюющей армии и других манипулятивных действий). Под эвфемизмами понимаются также «окказиональные индивидуально-контекстные замены одних слов другими с целью искажения или маскировки подлинной сущности обозначаемого» [25, c. 590$]$.

О связи эвфемизмов с темой манипуляции говорит Е. А. Земская: «Особая очень важная проблема < ..> сокрытие подлинной иллокутивной силы, прием маскировки истинного смысла речи. Сюда относятся, в частности, такие явления, как эвфемизация... [26, c. 125].

Однако, на наш взгляд, две последних цели (завуалированность и конфиденциальность) часто бывают взамосвязаны и являются двумя сторонами одного процесса, дополняя друг друга. С одной стороны, эвфемизмы вуалируют суть для непосвященных. С другой стороны, они выстраивают общение профессионалов таким образом, чтобы информация без утечек, четко достигала адресата. В качестве иллюстрации приведем несколько тематических групп эвфемизмов:

1) эвфемизмы, характеризующие ход, результаты и участников военных действий;

2) эвфемизмы, замещающие прямые наименования различных видов оружия;
3) эвфемизмы, обозначающие вспомогательные устройства и учреждения, используемые в военных целях;

4) эвфемизмы, камуфлирующие деятельность разведки;

5) эвфемизмы, связанные с темой ядерного вооружения.

Вышеуказанные группы покрывают тот пласт информации, который обслуживает секретные данные и поэтому камуфлируется, часто при помощи эвфемизации.

Сравним: в рус. яз.: разработка необычных видов оружия (имеется в виду бактериологическое оружие), нетрадиционные формы войны (имеются в виду формы войны, направленные на полное уничтожение живой силы противника с сохранением его военной техники), акция (спланированные действия, например, диверсионной группы), получить допуск (без указания объекта: к секретной документации, к секретной работе) и т. д.

В англ. яз.: absorption - a military conquest (поглощение - военный захват); conflict - a war (конфликт - война); collateral damage - killing or wounding civilians by mistake (сопутствующий урон - гибель или ранение гражданского населения, произошедшие по ошибке); combat ineffective - dead, seriously ill, or badly wounded (неэффективен в бою - погиб, серьезно болен или тяжело ранен); expended - killed (в расходе - убит); glasshouse - an army prison (дом из стекла - военная тюрьма).

В нем. яз.: Wühlschwein - Minenräumpanzer (землеройка - танк-тральщик); Verteidigungsfall, militärische Lösung - Krieg (случай, требующий принятия оборонительных мер - война); Verderb - Tod (порча, повреждение - гибель); sich von der Verpflegung abmelden - ums Leben kommen (быть снятым с довольствия - погибнуть); Kahn, Kasten - Gefängnis (лодка, ящик - тюрьма).

Интересно, что Л. П. Крысин причисляет к эвфемизмам и аббревиатуры, особенно характерные для сфер, связанных с сокрытием государственных и военных тайн: $B M=$ высшая мера (наказания), ДСП= для служебного пользования, $C C=$ совершенно секретно (гриф на документах; в профессиональном обиходе такой гриф именовался «два Семена») и др. [24].

Следует различать эвфемизацию (семантическую трансформацию) и аббревиацию (формальную, структурную трансформацию). Эвфемизмы отличаются от аббревиатур, кодов и шифров тем, что их форма достаточно эксплицитна и, на первый взгляд, значение развернутого, несокращенного термина ясно и не вызывает вопросов. Однако если вдуматься, то мы понимаем, что у анализируемой лексической единицы появляется новый скрытый смысл, который реа- 
лизуется лишь в заданном контексте. Имплицитность эвфемизмов проявляется не в форме, а в значении, а значение контекстуально. Эвфемизация строится на конфликте, противоречии прямого и переносного значений, эксплицитного, на поверхности, и имплицитного, скрытого, смыслов.

Напротив, аббревиатура не имеет прямого и переносного значений, в зону эксплицитности она попадает, если становится широко известной, вытесняя из употребления свой развернутый прототип. Например, аббревиатура RADAR вытеснила из речи свой прототип Radio Detection and Ranging (радиолокационная станция). Тем не менее такая ситуация не приводит к конфликту значений. По этой причине мы не считаем целесообразным ставить знак равенства между эвфемизмами и аббревиатурами.

\section{Результаты исследования}

Присутствие высокого уровня имплицитности в проанализированных единицах позволяет считать рассмотренные терминологические единицы наиболее перспективными для хранения, передачи и манипуляций с информацией, так как, вмещая внушительный объем профессиональных знаний, они не являются для потенциальных злоумышленников доступным средством ее получения. Более того, они удобны для использования профессионалами, так как легко запоминаются, ассоциативно связаны с коррелятом, эффективно помогают усваивать длинные инструкции и т. д.

Между тремя классами имплицитных единиц имеется разница в ракурсе имплицитности, т. е. где содержится скрытая информация и что является ключом к ее расшифровке. При использовании омоакронимов главную роль играет форма, ибо в любом лексико-синтаксическом окружении структура аббревиатуры сохраняется. Для распознания эвфемизмов контекст, напротив, играет определяющую роль. Вне определяющего окружения эвфемизм теряет свой скрывающий, сглаживающий эффект и превращается в эксплицитную ЛЕ, у которой форма передает ее означаемое, только и всего. Парадокс функционирования эвфемизмов заключается в том, что находится за пределами непосредственно лексической единицы - контекст, экстралингвистическая ситуация (например, с какой интонацией произнесена данная ЛЕ: нейтрально или иронично; содержится ли в ней намек или аллюзия к другому явлению или объекту; обладает ли данная ЛЕ коннотативным значением или нет, и т. д.)

Имплицитные ЛЕ составляют важный пласт военной лексики, чьи вышеуказанные преимущества делают их базовыми в процессе терминологического моделирования в военной сфере. Однако при работе с любым из классов возникают следующие сложно- сти: полисемия, омонимия, синонимия и эвфемия. Кроме того, можно встретить несколько форм сокращения одного и того же термина. Наоборот, за одной и той же оболочкой может стоять совершенно разное наполнение. Омонимия значительно затрудняет точное восприятие информации, более того, вводит реципиента в заблуждение, что совершенно неприемлемо в военной сфере, где неточность может стоить жизни людей и пагубно сказаться на безопасности страны.

Крайне актуальной становится задача составления справочника или корпуса примеров имплицитной военной лексики, что стало бы большим подспорьем при работе с аутентичными военными текстами.

Наконец, необходимо учить специалистов навыкам распознавать и грамотно истолковывать имплицитные единицы, что обеспечит эффективность восприятия контекста любой сложности, позволяя специалисту видеть то, что находится «между строк».

\section{ЛИТЕРАТУРА}

1. Судзиловский Г. А. Сленг - что это такое? Англо-русский словарь военного сленга. М. : Воениздат, 1973. 182 с.

2. Гальперин И. Р. Стилистика английского языка. 3-е изд. М. : ЛАБРИКОМ, 2010. 336 с.

3. Ахманова О. С. Словарь лингвистических терминов. М. : КомКнига, 2007. 576 с.

4. Бондарко A. В. Эксплицитность/имплицитность в общей системе категоризации семантики // Эксплицитность/имплицитность выражения смыслов. Калининград : Светлогорск, 2006. С. 24.

5. Арутюнова Н. Д. Язык и мир человека. М. : Языки русской культуры, 1999. 896 с.

6. Homer B. D., Ramsay J. T. Making Implicit Explicit : the Role of Learning // Behavioral and Brain Sciences. 1999. № 22 (5). URL: https://www.cambridge. org/ 485F4E89EE917192D6D211F6D8A8B088

7. Зубова Л. Ю., Ларина Т. В. Омоакронимия как отличительная черта англоязычного профессионального дискурса военнослужащих // Теория языка и межкультурная коммуникация. Электронный научный журнал Курского государственного университета. 2019. № 2 (33). C. 60-68. URL: https://www.elibrary. $\mathrm{ru} /$ item.asp? $\mathrm{id}=38487370$

8. Засурский Я. Н. Техника дезинформации и обмана. М., 1978. 246 с.

9. Кубрякова Е. С. О понятиях дискурса и дискурсивного анализа в современной лингвистике // Дискурс, речь, речевая деятельность : функциональные и структурные аспекты : сб. обзоров РАН ИНИОН (Сер.: Теория и история языкознания). М., 2000. С. 5-13.

10. Ярмашевич M. А. Специфика проявления семантического значения аббревиатур в языках различного типа. Саратов, 2003. 120 с. 
11. Молчанова Л. В., Зубова Л. Ю. Явление аббревиации в сопоставительном аспекте // Вестник Воронеж. гос. ун-та. Сер.: Лингвистика и межкультурная коммуникация. 2019. № 2. С. 120-129.

12. Арнольд И. В., Ардаматская Е. Н. Парадоксальность омоакронимии (на материале англ. мор. терминологии) // Продуктивность, частотность и валентность деривационных моделей. Владивосток, 1988. C. 3-12.

13. Большой российский энциклопедический словарь. М. : Большая рос. энцикл., 2003. 1887 с.

14. Большой энциклопедический словарь онлайн. M., 2000. URL: https://rus-big-enc-dict.slovaronline. com

15. Соловьева Ю. А. Концептуальная метафора в англоязычном научном политическом дискурсе : дис. ... канд. филол. наук. М., 2011. 210 c.

16. Порохницкая Л. В. Концептуальные основания эвфемии в языке : на материале английского, немецкого, французского, испанского и итальянского языков : дис. ... д-ра филол. наук. М., 2014. 420 с.

17. Sieminski G. The Art of Naming Operations. Newport, R.I. : Naval War College, 1995. 40 p.

18. Киселева С. А. Функционирование эвфемизмов в современном английском военно-политическом дискурсе (структурно-семантический и прагматический аспекты) : дис. ... канд. филол. наук. М., 2015. $240 \mathrm{c}$.

19. Арапова Н. С. Эвфемизмы. Лингвистический энциклопедический словарь / под ред. В. Н. Ярцева. M. : Сов. энциклопедия, 1990. URL: http://tapemark. narod.ru/les

20. Караулов Ю. Н. Языковая личность // Русский язык : энцикл. Изд. 2-е. М. : Дрофа, 1997. С. 671-672.

21. Михайлова О. А., Якименко Н. Е. Содержание понятия эвфемизм : к постановке проблемы // Слово. Фраза. Текст : [сб. науч. ст. к 60-летию проф. М. А. Алексеенко]. М., 2002. С. 280-284.

22. Кирсанова Н. Е., Карташкова Ф. И. Эвфемия и язык политической корректности // Молодая наука -2000 : сб. науч. трудов аспирантов и студентов. Ч. 3 . Иваново, 2000. С. 169-171.

23. Шапина Л. Н. Эвфемизмы в социальных сфеpax деятельности : политкорректность и «деревянный язык» (на примере французского языка). URL: http:// vestnik.adygnet.ru/files/2008.2/677/Shapina2008_2.pdf

24. Крысин Л. П. Эвфемизмы в современной русской речи // Русистика. Берлин, 1994. № 1-2. С. 28-49.

25. Лингвистический энциклопедический словарь / под ред. В. Н. Ярцева. М. : Сов. энцикл., 2000. 688 с. URL: http://tapemark.narod.ru/les/590c.html

26. Земская E. A. Активные процессы в современном русском языке последнего десятилетия XX века // Русская речь. 1998. № 7. С. 120-127.

\section{ИСТОЧНИКИ}

1. Rawson $\mathrm{H}$. A dictionary of euphemisms and other doubletalk. New York : Crown Publishers, Inc., 1981. 324 p. URL: https://vk.com/doc147039035_444653760? hash $=$ eb10fbb16a9cc4f $4 \mathrm{~b} 8$

2. Holder R. W. How Not to Say What You Mean. A Dictionary of Euphemisms. Oxford : Oxford University Press, 2002. 525 p. URL: https://vk.com/doc147039035 444651336?hash=05aaee13d2894399e8

3. Англо-русско-английский словарь военно-технических аббревиатур. M. : Pollyglossum, 2007. URL: http://www.ets.ru/pg/r/en_ru_en.htm

4. Англо-русский словарь аббревиатур, используемых в вооруженных силах США и НАТО. М. : Генеральный штаб Вооруженных сил РФ, Главное управление, 2003. $372 \mathrm{c.}$

5. Парпаров Л. Ф., Азарх Л. С. Немецко-русский словарь сокращений / под ред. Л. Ф. Парпарова. М. : Воениздат, $1983.320 \mathrm{c}$.

6. Таубе А. М. Военный немецко-русский словарь. М. : ОГИЗ, 1945. 611 с.

\section{REFERENCES}

1. Sudzilovsky G. A. Slang - what is it? English Russian dictionary of military slang. M.: Voenizdat, 1973. $182 \mathrm{p}$.

2. Galperin I. R. Stylistics of the English language. 3rd ed. M.: Book House LABRIKOM, 2010.336 p.

3. Akhmanova O. S. Dictionary of linguistic terms. Moscow: KomKniga, 2007. 576 p.

4. Bondarko A. V. Explicitness/Implicitness in the general system of categorization of semantics. In: Explicitness / implicitness of the expression of meanings. Kaliningrad: Svetlogorsk, 2006. P. 24.

5. Arutyunova N. D. Language and the world of man. Moscow: Languages of Russian Culture, 1999. 896 p.

6. Homer B. D., Ramsay J. T. Making Implicit Explicit: the Role of Learning. In: Behavioral and Brain Sciences. 1999. № 22 (5). Available at: https://www. cambridge.org/ 485F4E89EE917192D6D211F6D8A 8B088

7. Zubova L. Yu., Larina T. V. Homoacronymya as a distinctive feature of the English language professional discourse of military personnel. In: Theory of language and intercultural communication. Electronic scientific Journal of Kursk State University. 2019. No. 2 (33). Pp. 60-68. Available at: https://www.elibrary.ru/item. asp?id $=38487370$

8. Zasursky Ya. N. Tehnika disinformatsii i obmana [Technique of disinformation and deception]. M., 1978. $246 \mathrm{p}$.

9. Kubryakova E. S. On the concepts of discourse and discursive analysis in modern linguistics. In: Discourse, speech, speech activity: functional and structural 
aspects: Collection of reviews of the Russian Academy of Sciences INION (Series: Theory and History of Linguistics). M., 2000. Pp. 5-13.

10. Yarmashevich M. A. Specificity of the semantic meaning of abbreviations in languages of various types. Saratov, 2003. 120 p.

11. Molchanova L. V., Zubova L. Yu. The phenomenon of abbreviation in the comparative aspect. In: Bulletin of the Voronezh State University. Series: Linguistics and intercultural communication. 2019. No. 2. Pp. 120-129.

12. Arnold I. V., Ardamatskaya E. N. Paradox of homoacronymya: (based on the material of English marine terminology). In: Productivity, frequency, and valence of derivational models. Vladivostok, 1988. Pp. 3-12.

13. Big Russian Encyclopedia. M.: A Large ros. encyclopaedia, 2003. 1887 p.

14. Big Encyclopedia online. Moscow, 2000. Available at: https://rus-big-enc-dict.slovaronline.com

15. Solov'eva Yu. A. Conceptual metaphor in the English language scientific political discourse: dis. ... Candidate of Philological Sciences. M., 2011. 210 p.

16. Porokhnitskaya L. V. Conceptual foundations of euphemia in language: on the material of English, German, French, Spanish and Italian languages: dis. ... Doctor of Philology. M., 2014. 420 p.

17. Sieminski G. The Art of Naming Operations. Newport, R.I.: Naval War College, 1995. 40 p.

18. Kiseleva S. A. Functioning of euphemisms in modern English military-political discourse (structuralsemantic and pragmatic aspects): dis. ... Candidate of Philological Sciences. M., 2015. 240 p.

19. Arapova N. S. Euphemisms. Linguistic encyclopedic dictionary / Edited by V. N. Yartsev. M., Soviet Encyclopedia, 1990. Available at: http://tapemark.narod. $\mathrm{ru} / \mathrm{les}$

20. Karaulov Yu. N. Yazykovaya lichnost ' [Linguistic personality]. In: Russian language : encycl. Ed. 2. M.: Drofa, 1997. Pp. 671-672.

21. Mikhailova O. A., Yakimenko N. E. The content of the concept of euphemism: to the formulation of the problem. In: Word. The phrase. [Sbornik nauchnyh statei

Военный учебно-научный изентр Военно-воздушных сил «Военно-воздушная академия имени профессора Н. Е. Жуковского и Ю. А. Гагарина»

Молчанова Л. В., кандидат филологических наук, дочент, профессор кафедры иностранных языков

E-mail:molchanowa@rambler.ru

Зубова Л. Ю., кандидат филологических наук, доиеетт кафедры иностранных языков

E-mail: lucie-lucy@mail.ru on the 60th anniversary of Professor M. A. Alekseenko]. M., 2002. Pp. 280-284.

22. Kirsanova N. E., Kartashova F. I. Euphemia and the language of political correctness. In: Young science 2000: Sbornik nauchnyh trudov by graduate and undergraduate students. Part 3. Ivanovo, 2000. Pp. 169-171.

23. Supina L. N. Euphemisms in social spheres: political correctness and the "wooden language" (on the example of the French language). Available at: http:// vestnik.adygnet.ru/files/2008.2/677/Shapina2008_2.pdf

24. Krysin L. P. Euphemisms in modern Russian speech. In: Russian studies. Berlin, 1994. No. 1-2. Pp. 28-49.

25. Linguistic Encyclopedia / Under the editorship of V. N. Yartseva. M.: Sov. encikl., 2000. 688 p. Available at: http://tapemark.narod.ru/les/590c.html

26. Zemskaya E. A. Active processes in the modern Russian language of the last decade of the XX century. In: Russkaya rech. 1998. No. 7. Pp. 120-127.

\section{SOURCES}

1. Rawson H. A dictionary of euphemisms and other doubletalk. New York: Crown Publishers Inc., 1981. 324 p. Available at: https://vk.com/doc147039035 444653760?hash=eb10fbb16a9cc4f4b8

2. Holder R. W. How Not to Say What You Mean. A Dictionary of Euphemisms. Oxford: Oxford University Press, 2002. 525 p. Available at: https://vk.com/doc147 039035_444651336?hash $=05$ aaee $13 \mathrm{~d} 2894399 \mathrm{e} 8$

3. English-Russian-English dictionary of military-technical abbreviations. Moscow, Pollyglossum, 2007. Available at: http://www.ets.ru/pg/r/en_ru_en.htm

4. English-Russian dictionary of abbreviations used in the armed forces of the United States and NATO. Moscow: General Staff of the Armed Forces of the Russian Federation, Main Directorate, 2003. 372 p.

5. Parparov L. V., Asarh L. S. Deutsch-Russisches Wörterbuch der Abkürzungen / Unter der Redaktion von L.V. Parparov. M.: Voenizdat, 1983. 320 S.

6. Taube A. M. Militärisches deutsch-russisches Wörterbuch. M.: OGIZ, 1945. $611 \mathrm{~S}$.

Military Educational and Scientific Center of the Air Force «N. E. Zhukovsky and Yu. A. Gagarin Air Force Academy»

Molchanova L. V., Candidate of Philology, Associate Professor, Professor of the Foreign Languages Department E-mail:molchanowa@rambler.ru

Zubova L. Yu., Candidate of Philology, Associate Professor of the Foreign Languages Department

E-mail: lucie-lucy@mail.ru 
Поступила в редакциию 24 февраля 2021 г.

Принята к публикации 22 марта 2021 г.

\section{Для цитирования:}

Молчанова Л. В., Зубова Л. Ю. Имплицитность профессионального языка военнослужащих: семантико-стилистические нюансы успешного коммуницирования // Вестник Воронежского государственного университета. Серия: Лингвистика и межкультурная коммуникация. 2021. № 2. С. 23-35. DOI: https://doi.org/10.17308/ lic. $2021.2 / 3412$

\section{Received: 24 February 2021}

Accepted: 22 March 2021

\section{For citation:}

Molchanova L. V., Zubova L. Yu. Implicitness of the military professional language: semantic and stylistic nuances of successful communication. Proceedings of Voronezh State University. Series: Linguistics and Intercultural Communication. 2021. No. 2. Pp. 23-35. DOI: https://doi. org/10.17308/lic.2021.2/3412 